\title{
Genetic Relationships Among Magnaporthe poae Isolates from Turfgrass Hosts and Relative Susceptibility of 'Penncross' and 'Penn A-4' Creeping Bentgrass
}

\author{
L. P. Tredway, Department of Plant Pathology, North Carolina State University, Raleigh 27695
}

\begin{abstract}
Tredway, L. P. 2006. Genetic relationships among Magnaporthe poae isolates from turfgrass hosts and relative susceptibility of 'Penncross' and 'Penn A-4' creeping bentgrass. Plant Dis. 90:1531-1538.

Isolates of Magnaporthe poae from turfgrass hosts were analyzed for mating type, genetic relatedness according to ITS sequences, reaction to a previously developed species-specific polymerase chain reaction (PCR) assay, and virulence on two creeping bentgrass cultivars in growth chamber experiments. Analysis of internal transcribed spacer (ITS) sequences revealed three clades, designated A, B, and C. Clade A contained isolates of both mating types from creeping bentgrass, annual bluegrass, and Kentucky bluegrass. Clade B contained only mating type 'A' isolates from annual bluegrass, whereas Clade $\mathrm{C}$ contained only mating type ' $\mathrm{a}$ ' isolates from creeping bentgrass. The $M$. poae PCR assay failed to positively identify several North Carolina isolates from annual bluegrass and creeping bentgrass. M. poae isolates from Kentucky bluegrass were most virulent toward creeping bentgrass in growth chamber experiments. Although isolates of M. poae are not host specific, certain ITS clades may have a limited host or geographical range. The improved creeping bentgrass cv. Penn A-4 was more susceptible to summer patch than cv. Penncross. Additional research is needed to develop methods for accurate diagnosis of summer patch and other patch diseases in creeping bentgrass and to determine how creeping bentgrass cultivars vary in their susceptibility to these root pathogens.
\end{abstract}

Additional keyword: Agrostis

Fungal species in the genera Gaeumannomyces, Magnaporthe, and Ophiosphaerella (Pyrenomycetes and Loculoascomycetes, Ascomycota) are common pathogens of gramineous hosts, causing necrosis of belowground plant tissue. These pathogens colonize host surfaces with darkly pigmented runner hyphae, then produce hyphopodia that facilitate penetration of host tissue. Garret (6) coined the term "ectotrophic" to describe the growth habit of these pathogens, which now commonly are referred to as ectotrophic root-infecting (ETRI) fungi. Continued infection and colonization leads to extensive necrosis of roots, crowns, stolons, or rhizomes, eventually causing dieback of aboveground tissue.

ETRI fungi cause a group of turfgrass diseases that commonly are referred to as "patch diseases," based on the appearance of symptoms in circular patches or rings ranging from 0.1 to $1 \mathrm{~m}$ in diameter (7). Most of the major grass species grown for turf are affected by one or more patch disease, but each pathogen has a limited host range. Among cool-season (C3)

Corresponding author: L. P. Tredway

E-mail: lane_tredway@ncsu.edu

Accepted for publication 11 July 2006.

DOI: 10.1094/PD-90-1531

(C) 2006 The American Phytopathological Society turfgrass species, Gaeumannomyces graminis var. avenae causes take-all patch of bentgrasses (Agrostis spp.), Magbluegrasses (Poa spp.) and fine-leaved fescues (Festuca spp.), and Ophiosphaerella korrae causes necrotic ring spot of bluegrasses (7).

Creeping bentgrass (Agrostis palustris Huds.) is the predominant grass species grown for golf course putting greens in temperate and subtropical climates. Takeall patch, caused by G. graminis var. avenae, is an important disease of creeping bentgrass in temperate regions but is not commonly observed in subtropical climates (7). G. graminis var. avenae infects and colonizes creeping bentgrass roots in the fall and spring when soil temperatures are between 4 and $15^{\circ} \mathrm{C}$; however, symptoms typically are not observed until late spring or early summer, when heat or drought stress induce the expression of aboveground symptoms (3).

$M$. poae, the causal agent of summer patch, has been associated with creeping bentgrass, but the significance of this hostpathogen relationship in the field has received little attention. In growth chamber M. poae isolate from Kentucky bluegrass (Poa pratensis) was pathogenic to 'Penncross' creeping bentgrass; however, this host was more tolerant of the pathogen than annual bluegrass ( $P$. апnиa L.). Elliot (5) isolated $M$. poae from creeping bentnaporthe poae incites summer patch of studies, Landschoot (12) showed that an grass exhibiting patch disease symptoms in Florida and also demonstrated its pathogenicity to Penncross and 'SR-1020' in controlled environments. The author attributed this occurrence to culture of creeping bentgrass in a tropical climate, outside of the normal range of adaptation for this species.

In 2002 and 2003, typical patch disease symptoms were observed on creeping bentgrass at The Country Club of Landfall in Wilmington, NC. Affected greens were established in 2001 with a 50:50 blend of cvs. Penn A-1 and Penn A-4, with soil pH ranging from 7 to 8 due to use of poorquality irrigation water. Disease symptoms appeared in June of each year in circular patches, ranging from 0.3 to $1 \mathrm{~m}$ in diameter, which initially exhibited signs of wilt followed by chlorosis and orange necrosis. The disease initially was diagnosed as take-all patch based on observation of necrotic roots and crowns that were colonized with dark, ectotrophic hyphae. However, the late appearance of symptoms and historical lack of take-all patch occurrence in this region led to the suspicion that $G$. graminis var. avenae was not involved. $M$. poae was isolated consistently from necrotic root and crown tissue, and pathogenicity of this species was demonstrated in controlled environments and in the field (19). These results demonstrate that $M$. poae can be pathogenic to creeping bentgrass within its zone of adaptation.

Prior to the discovery of summer patch in creeping bentgrass, take-all patch was the only patch disease associated with this turfgrass species. As a result, take-all patch commonly was diagnosed through observation of necrotic root, crown, and stolon tissue that was colonized with darkly pigmented ectotrophic hyphae (17). However, $M$. poae and $G$. graminis are difficult to distinguish due to a lack of reliable morphological characteristics for identification. The occurrence of summer patch in creeping bentgrass highlights the need for accurate methods for diagnosis of diseases caused by ETRI fungi. Polymerase chain reaction (PCR)-based methods for identification of G. graminis var. avenae $(4,16,22)$ and $M$. poae (2) have been developed but are not widely used in diagnostic clinics.

Since the early 1990s, a new generation of creeping bentgrass cultivars has been developed for use in golf course putting greens $(1,11)$. These grasses were selected primarily for agronomic characteristics and tolerance to abiotic stresses, such as heat, 
drought, and close mowing. These cultivars also vary in their resistance or susceptibility to certain turfgrass diseases when compared with cv. Penncross. For example, some of the new cultivars are more susceptible to dollar spot, a foliar disease caused by Sclerotinia homoeocarpa, than older cultivars such as Penncross (21) but, in general, are more resistant to take-all patch (23). The relative susceptibility of creeping bentgrass cultivars to infection by $M$. poae is unknown and warrants investigation.

The objectives of this study were to determine the genetic relationships among $M$. poae isolates from various turfgrass hosts, test a previously developed PCR-based method for identification of M. poae (2), determine the pathogenicity of $M$. poae isolates from turfgrass hosts to creeping bentgrass, and evaluate the relative susceptibility of Penncross and Penn A-4 creeping bentgrass to infection by M. poae.

\section{MATERIALS AND METHODS}

Isolate collection and in vitro mating. Isolates of $M$. poae were obtained from creeping bentgrass, Kentucky bluegrass, and annual bluegrass turf exhibiting summer patch symptoms in North Carolina in 2002 and 2003 (Table 1). Necrotic root and crown tissue was surface disinfested in $1 \%$ $\mathrm{AgNO}_{3}$ for 1 min followed by precipitation in $5 \% \mathrm{NaCl}$ for $30 \mathrm{~s}$ or in $0.6 \% \mathrm{NaOCl}$ for 5 min. Disinfested tissue was plated on potato dextrose agar amended with tetracycline, streptomycin, and chloramphenicol (PDA+++), each at $50 \mathrm{mg} / \mathrm{kg}$, or on selective medium SMGGT3 (8) and incubated at $25^{\circ} \mathrm{C}$. Colonies arising from necrotic tissue were transferred to fresh plates of PDA+++. Additional isolates from annual bluegrass and Kentucky bluegrass were obtained from the American Type Culture Collection (ATCC, Manassas, VA), B. B. Clarke (Rutgers University, New Brunswick, NJ), and P. J. Landschoot (Pennsylvania State University, University Park). Isolates were prepared for long-term storage by transferring to PDA+++ overlaid with autoclaved filter paper sections. Once infested with mycelia, the filter paper sections were removed from the agar surface, placed in a coin envelope, dried overnight in a laminar flow hood, and stored in card file boxes at $-80^{\circ} \mathrm{C}$.

Production of the teleomorph through mating with known tester strains is the most reliable method for identification of M. poae (14). Isolates 73-15 (mating type 'A') and 73-1 (mating type 'a') initially were employed as tester strains in this study. However, repeated attempts to mate 73-15 and 73-1 yielded no reaction, even though 73-15 mated successfully with several other isolates. Therefore, it was concluded that 73-1 had become sterile during many years of maintenance in culture. Isolate SCR4 was selected as the mating type ' $a$ ' tester strain for this study based on its high fecundity when paired with 73-15.

Mating was conducted in vitro on Sachs agar (15) overlaid with six to eight autoclaved wheat stem sections. Each unknown isolate was crossed with $M$. poae tester isolates of known mating type. Plugs of PDA+++ infested with an unknown isolate were transferred to the perimeter of Sachs agar plates in two locations, $180^{\circ}$ apart. A tester strain then was transferred to the perimeter of the plate in two locations $90^{\circ}$ from each unknown plug. Mating plates were incubated at room temperature under continuous fluorescent illumination and were observed weekly for presence of perithecia. Matings for each isolate were conducted in at least two independent experiments.

Molecular characterization. Each isolate was grown for 7 days at room temperature $\left(23\right.$ to $\left.25^{\circ} \mathrm{C}\right)$ in $2 \mathrm{ml}$ of potato dextrose broth. The mycelial suspension was transferred to a $1.5-\mathrm{ml}$ microcentrifuge tube, harvested by centrifugation for $5 \mathrm{~min}$ at 13,200 rpm, and genomic DNA was extracted using the Easy-DNA Kit (Invitrogen Corp., Carlsbad, CA). Genomic DNA was quantified by spectrophotometry at $260 \mathrm{~nm}$, then standardized to 50 $\mathrm{ng} / \mu \mathrm{l}$.

PCR amplification of ribosomal (r)DNA regions internal transcribed spacer (ITS)1, 5.8S rRNA, and ITS2 was performed using primers ITS5 and ITS4 (24). PCR reac-

Table 1. Origin of Magnaporthe isolates and results of mating crosses, Magnaporthe poae polymerase chain reaction (PCR) assays, and phylogenetic analysis of ribosomal (r)DNA sequences ${ }^{\mathrm{y}}$

\begin{tabular}{|c|c|c|c|c|c|c|c|c|c|}
\hline Species & Isolate & Host species & Origin & Year & $\begin{array}{c}\text { Mating } \\
\text { type }\end{array}$ & $\begin{array}{c}\text { M. poae } \\
\text { PCR }\end{array}$ & $\begin{array}{l}\text { rDNA } \\
\text { clade }\end{array}$ & $\begin{array}{l}\text { GenBank } \\
\text { accession }\end{array}$ & Reference \\
\hline M. poae & 73-1 (ATCC-64412) & Lab strain & N/A & 1985 & $\mathrm{UC}^{\mathrm{z}}$ & + & A & DQ528764 & 13 \\
\hline M. poae & 73-15 (ATCC-64411) & Lab strain & N/A & 1985 & $\mathrm{~A}$ & + & $\mathrm{B}$ & DQ528765 & 13 \\
\hline M. poae & Poa3 & Annual bluegrass & Wilmington, NC & 2003 & $\mathrm{a}$ & - & A & DQ528766 & $\ldots$ \\
\hline M. poae & Poa4 & Annual bluegrass & Wilmington, NC & 2003 & $\mathrm{a}$ & - & A & DQ528767 & $\ldots$ \\
\hline M. poae & Poa5 & Annual bluegrass & Wilmington, NC & 2003 & a & - & A & DQ528768 & $\ldots$ \\
\hline M. poae & Poa6 & Annual bluegrass & Wilmington, NC & 2003 & $\mathrm{a}$ & - & A & DQ528769 & $\ldots$ \\
\hline M. poae & LMAD & Annual bluegrass & Marlton, NJ & 1988 & A & + & B & DQ528770 & $\ldots$ \\
\hline M. poae & OakA5 & Annual bluegrass & Ambler, PA & 1988 & A & + & $\mathrm{B}$ & DQ528771 & 2 \\
\hline M. poae & NavA6 & Annual bluegrass & Navesink, NJ & 1988 & ST & + & $\mathrm{B}$ & DQ528772 & 2 \\
\hline M. poae & ATCC-64131 & Annual bluegrass & Providence, RI & 1985 & A & + & B & DQ528773 & 13 \\
\hline M. poae & Bent4 & Creeping bentgrass & Jackson Springs, NC & 2003 & $\mathrm{a}$ & - & A & DQ528774 & $\ldots$ \\
\hline M. poae & Bent5 & Creeping bentgrass & Jackson Springs, NC & 2003 & $\mathrm{a}$ & - & A & DQ528775 & $\ldots$ \\
\hline M. poae & Bent2 & Creeping bentgrass & Wilmington, NC & 2003 & ST & - & A & DQ528776 & $\ldots$ \\
\hline M. poae & Bent8 & Creeping bentgrass & Wilmington, NC & 2003 & ST & - & A & DQ528777 & $\ldots$ \\
\hline M. poae & Bent9 & Creeping bentgrass & Wilmington, NC & 2003 & $\mathrm{a}$ & - & A & DQ528778 & $\ldots$ \\
\hline M. poae & TAP41 & Creeping bentgrass & Wilmington, NC & 2002 & $\mathrm{a}$ & - & $\mathrm{A}$ & DQ528779 & 19 \\
\hline M. poae & TAP42 & Creeping bentgrass & Wilmington, NC & 2002 & ST & - & A & DQ528780 & 19 \\
\hline M. poae & SCR4 & Creeping bentgrass & Wilmington, NC & 2003 & $\mathrm{a}$ & + & $\mathrm{C}$ & DQ528781 & 19 \\
\hline M. poae & SCR10 & Creeping bentgrass & Wilmington, NC & 2003 & $\mathrm{a}$ & + & $\mathrm{C}$ & DQ528782 & $\ldots$ \\
\hline M. poae & TAP35 & Creeping bentgrass & Wilmington, NC & 2002 & a & + & $\mathrm{C}$ & DQ528783 & 19 \\
\hline M. poae & TAP36 & Creeping bentgrass & Wilmington, NC & 2002 & a & + & $\mathrm{C}$ & DQ528784 & $\ldots$ \\
\hline M. poae & TAP52 & Creeping bentgrass & Wilmington, NC & 2002 & $\mathrm{a}$ & + & $\mathrm{C}$ & DQ528785 & $\ldots$ \\
\hline M. poae & TAP62 & Creeping bentgrass & Wilmington, NC & 2002 & ST & + & $\mathrm{C}$ & DQ528786 & $\ldots$ \\
\hline M. poae & KBG3 & Kentucky bluegrass & Raleigh, NC & 2003 & $\mathrm{~A}$ & + & A & DQ528787 & $\ldots$ \\
\hline M. poae & KBG5 & Kentucky bluegrass & Raleigh, NC & 2003 & A & + & A & DQ528788 & $\ldots$ \\
\hline M. poae & KBG7 & Kentucky bluegrass & Raleigh, NC & 2003 & A & + & A & DQ528789 & $\ldots$ \\
\hline M. rhizophila & ATCC-96043 & Kentucky bluegrass & University Park, PA & 1992 & NP & + & $\mathrm{E}$ & DQ528790 & 14 \\
\hline M. rhizophila & $\operatorname{Mr} 4757$ & Unk & Unk & Unk & $\mathrm{ST}$ & + & $\mathrm{E}$ & DQ528791 & $\ldots$ \\
\hline M. salvinii & ATCC-44754 & Rice & Unk & Unk & NP & + & $\mathrm{F}$ & DQ528792 & 20 \\
\hline
\end{tabular}

y N/A = not applicable, ST = isolates yielded no mating reaction with either mating type and are presumed sterile, Unk = information unavailable or unknown, and NP = mating assays were not performed.

z Mating type of isolate 73-1 is known to be "a," but was not confirmed in this study due to apparent sterility of culture. 
tions were $50 \mu \mathrm{l}$ in volume and consisted of $20 \mathrm{mM}$ Tris- $\mathrm{HCl}$ (pH 8.3), $50 \mathrm{mM} \mathrm{KCl}$, $1.5 \mathrm{mM} \mathrm{MgCl}_{2}, 200 \mu \mathrm{M}$ each dNTP, 200 $\mathrm{nM}$ each primer, $1.5 \mathrm{U}$ of Taq polymerase (Invitrogen Corp., Carlsbad, CA), and 50 ng of genomic DNA. Thermal cycling conditions involved an initial denaturation step at $95^{\circ} \mathrm{C}$ for $3 \mathrm{~min}$; followed by 33 cycles of $95^{\circ} \mathrm{C}$ for $30 \mathrm{~s}, 58^{\circ} \mathrm{C}$ for $1 \mathrm{~min}$, and $72^{\circ} \mathrm{C}$ for $45 \mathrm{~s}$; and a final extension step at $72^{\circ} \mathrm{C}$ for $10 \mathrm{~min}$. Amplification products were purified with a Qiaquick PCR Purification Kit (Qiagen Inc., Valencia, CA). Cycle sequencing reactions were performed using an ABI Prism BigDye Terminator v3.0 Ready Reaction Cycle Sequencing Kit (Applied Biosystems Inc., Foster City, CA). Reactions were cleaned using Centrisep columns (Princeton Separations Inc., Adelphia, NJ), dried, then submitted to the University of Iowa DNA Sequencing Facility (Iowa City) for electrophoresis and fluorometric analysis. All sequences were aligned using the ClustalW method in MegAlign (5.05; DNASTAR Inc., Madison, WI) and adjusted by visual examination. A phylogenetic tree was constructed in MEGA 2.1 (10) using the neighbor-joining algorithm from genetic distances calculated using the Kimura twoparameter model using $M$. salvinii ATCC44754 as an outgroup. Bootstrap values were calculated in MEGA 2.1 based on 1,000 random samples of the data set.

A PCR-based assay for identification of $M$. poae developed by Bunting et al (2) was employed. This method uses primers P1 and P2 to amplify a 453-bp region of locus pMp2-7. PCR reactions were $25 \mu \mathrm{l}$ in volume and contained $50 \mathrm{ng}$ of template DNA, $20 \mathrm{mM}$ Tris-HCl (pH 8.3), $50 \mathrm{mM}$ $\mathrm{KCl}, 1.5 \mathrm{mM} \mathrm{MgCl} 2,0.5 \mathrm{U}$ of Taq DNA polymerase, 200 nmoles of primers $\mathrm{P} 1$ and P2, and $0.2 \mathrm{mM}$ each dNTP. Thermal cycling conditions involved an initial denaturation step at $94^{\circ} \mathrm{C}$ for $1 \mathrm{~min}$; followed by 30 cycles of $94^{\circ} \mathrm{C}$ for $30 \mathrm{~s}, 50^{\circ} \mathrm{C}$ for $1 \mathrm{~min}$, and $72^{\circ} \mathrm{C}$ for $1 \mathrm{~min}$; and a final extension step at $72^{\circ} \mathrm{C}$ for $1 \mathrm{~min}$. PCR products were separated in a $1 \%$ agarose gel at $80 \mathrm{~V}$ for 1 $\mathrm{h}$ and visualized by staining with ethidium bromide followed by UV illumination. All PCR reactions were repeated a minimum of three times, and primers ITS4 and ITS5 were employed as positive controls as described above.

Growth chamber inoculations. Conetainers $(3.8$ by $20 \mathrm{~cm}$ ) containing calcined clay (Turface Allsport, Profile Products LLC, Buffalo Grove, IL) were seeded with creeping bentgrass cvs. Penncross or Penn A-4 at a rate of $9.7 \mathrm{~g} \mathrm{~m}^{-2}$. The cone-tainers were transferred to a greenhouse, covered with paper, and misted twice per day to encourage rapid seed germination. After germination, the turf was maintained in the greenhouse by irrigating twice daily with a complete nutrient solution containing nitrogen at $106.23 \mathrm{~mol} \mathrm{~m}^{-3}$, phosphorus at $10.41 \mathrm{~mol} \mathrm{~m}^{-3}$, and potassium at 111.03 mol $\mathrm{m}^{-3}$. The turf was cut weekly with scissors to a height of $1.27 \mathrm{~cm}$.

Eight weeks after seeding, each conetainer was inoculated with sterilized rye grain (Secale cereale L.; $200 \mathrm{~g}$ of grain, $5.75 \mathrm{~g}$ of $\mathrm{CaCO}_{3}$, and $220 \mathrm{ml}$ of $\mathrm{H}_{2} \mathrm{O}$ ) infested with one of nine $M$. poae isolates. An individual grain was placed between the cone-tainer wall and calcined clay just below the soil surface in four locations approximately $90^{\circ}$ apart. Uninfested grain was included to serve as an uninoculated control. After inoculation, the cone-tainers were transferred to growth chambers with 12-h day/night cycles at $30 / 25^{\circ} \mathrm{C}, 35 / 25^{\circ} \mathrm{C}$, or $40 / 25^{\circ} \mathrm{C}$ and arranged in a split-plot randomized complete block with three replications, with cultivars serving as the main plots and isolates as the subplots.

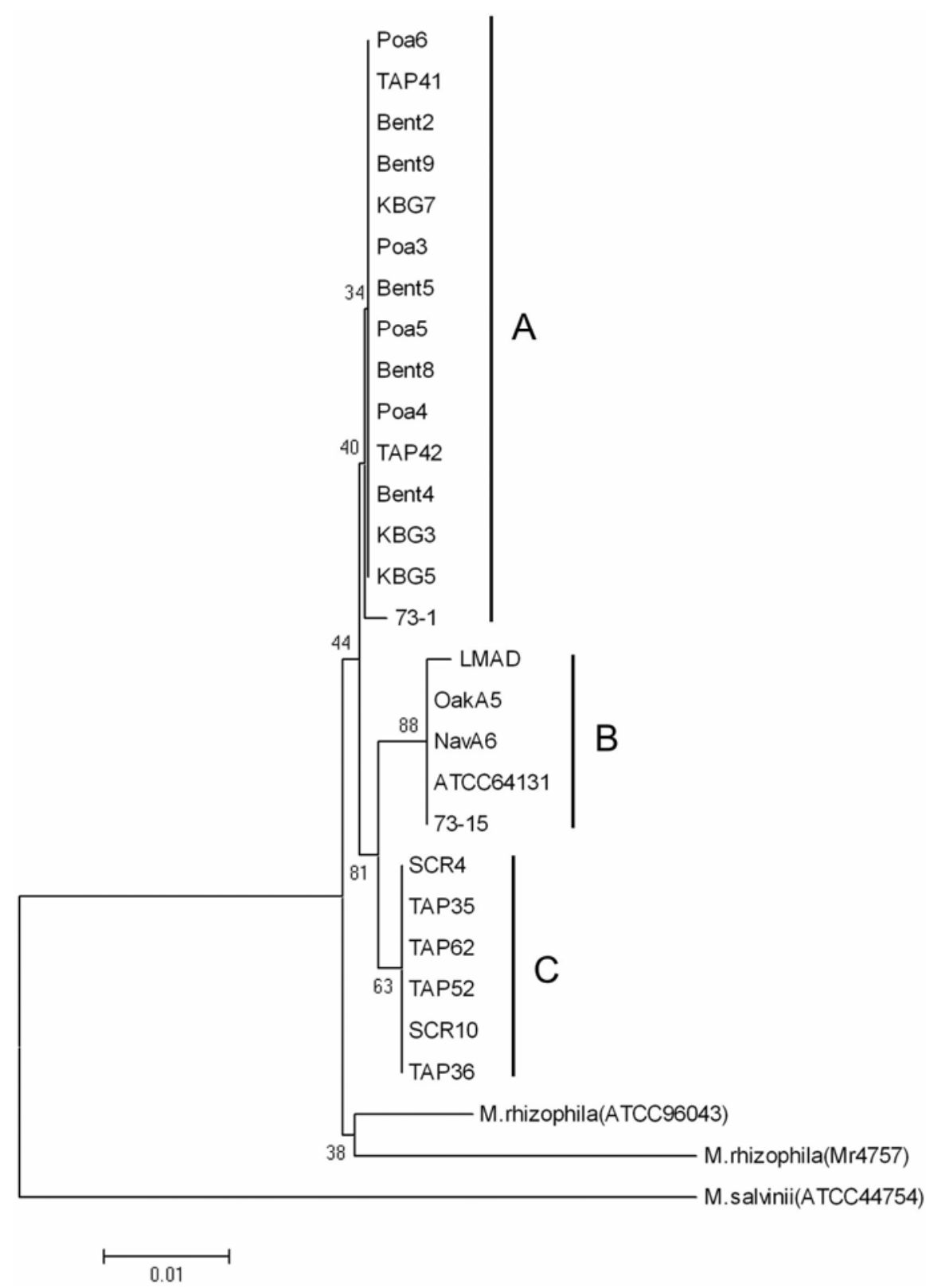

Fig. 1. Neighbor joining phylogram of Magnaporthe spp. produced from sequences of ribosomal DNA regions internal transcribed spacer (ITS) 1, 5.8S, and ITS2. Scale bar indicates the horizontal distance corresponding to genetic distance as calculated by the Kimura 2-parameter model. Bootstrap values are indicated adjacent to the nodes and are based on 1,000 resamplings of the data set.
The severity of disease symptoms was assessed 8 weeks after inoculation using a centage of foliar tissue exhibiting chlorosis or dieback $(10=100 \%, 5=50 \%$, and $0=$ $0 \%)$. The cone-tainers were cut with scissors to a height of $1.27 \mathrm{~cm}$ after evaluation and returned to the growth chambers for an additional 2 weeks, at which time foliar growth was assessed by removing and weighing the foliage to a height of $1.27 \mathrm{~cm}$ with scissors. Because of inherent differences among Penncross and Penn A-4 in foliar growth rate (data not shown), foliar growth data is expressed as a percentage of the uninoculated control. Growth chamber experiments were repeated twice.

All statistical analyses were performed in SAS (version 8.02; SAS Inc., Cary, scale of 0 to 10 , corresponding to the per- 
NC). Experiments conducted in different temperatures were analyzed separately. Analysis of variance was conducted using PROC GLM to estimate the effects of cultivar, isolate, replication, and cultivarisolate interactions on disease severity and foliar growth. The Waller-Duncan $k$ ratio $t$ test $(k=100)$ was used to separate means for comparisons among $M$. poae isolates. Linear contrasts also were used to test for significant differences in the virulence of isolates from different turfgrass hosts.

\section{RESULTS}

In vitro mating. Of the $26 \mathrm{M}$. poae isolates in the sample population, 6 yielded no mating reaction when paired with either 73-15 or SCR4 in vitro, and these isolates were presumed to be sterile (Table 1). The sterile isolates included 73-1 and NavA6, which are known M. poae isolates collected from Poa spp. in 1984 and 1988, respectively. However, four isolates obtained from creeping bentgrass in North Carolina in 2002 and 2003 also yielded no mating reaction in vitro.

Of the $M$. poae isolates that exhibited a mating response, all North Carolina isolates from annual bluegrass and creeping bentgrass mated with tester strain 73-15 and, therefore, were classified as mating type ' $a$ '. In contrast, all three annual bluegrass isolates from the northeastern United States (New Jersey, Pennsylvania, and Rhode Island) and all North Carolina isolates from Kentucky bluegrass were mating type 'A'.

Molecular characterization. All known isolates of $M$. poae from New Jersey, Pennsylvania, and Rhode Island yielded a positive reaction using the $M$. poaespecific primers developed by Bunting et al (2; Table 1). In addition, isolates of $M$. rhizophila and $M$. salvinii also produced a positive reaction. None of the $4 M$. poae isolates obtained from annual bluegrass in North Carolina yielded a positive reaction, along with 7 of the 13 isolates from creeping bentgrass. All three of the M. poae isolates from Kentucky bluegrass in North Carolina were positively identified by this PCR assay.

Phylogenetic analysis of rDNA-ITS sequences revealed three distinct clades, designated $\mathrm{A}, \mathrm{B}$, and $\mathrm{C}$, within $M$. poae (Fig. 1). Only clade B was distinguished by a significant bootstrap support value of 88. Clade A contained isolate 73-1 (ATCC64412), one of the $M$. poae-type isolates described by Landschoot and Jackson (14).
This clade also contained the 7 isolates obtained from bluegrasses in North Carolina and 7 of the 13 isolates from creeping bentgrass. Clade A contained both mating types as well as several sterile isolates. The annual bluegrass and creeping bentgrass isolates in clade $\mathrm{A}$ all yielded a negative reaction with the $M$. poae $\mathrm{PCR}$ assay.

Clade B contained isolate 73-15 (ATCC64411), the other $M$. poae type isolate included in this study. This clade also contained the four annual bluegrass isolates

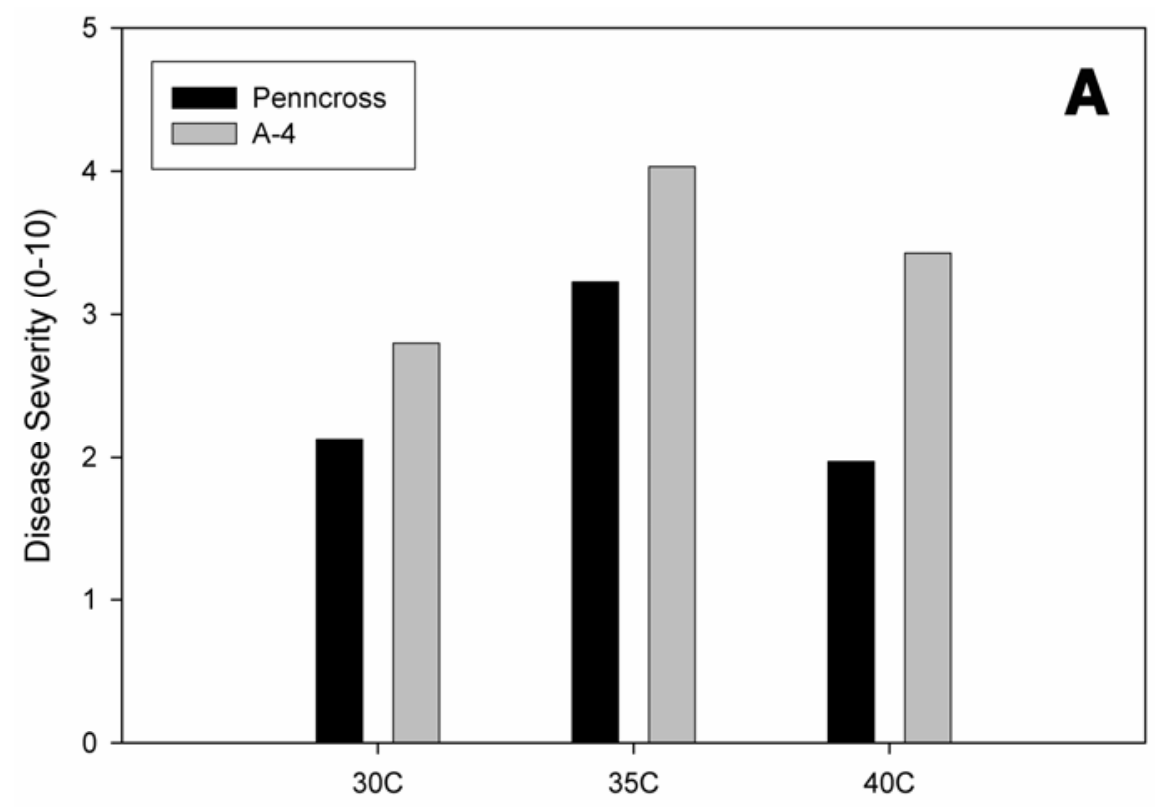

Temperature

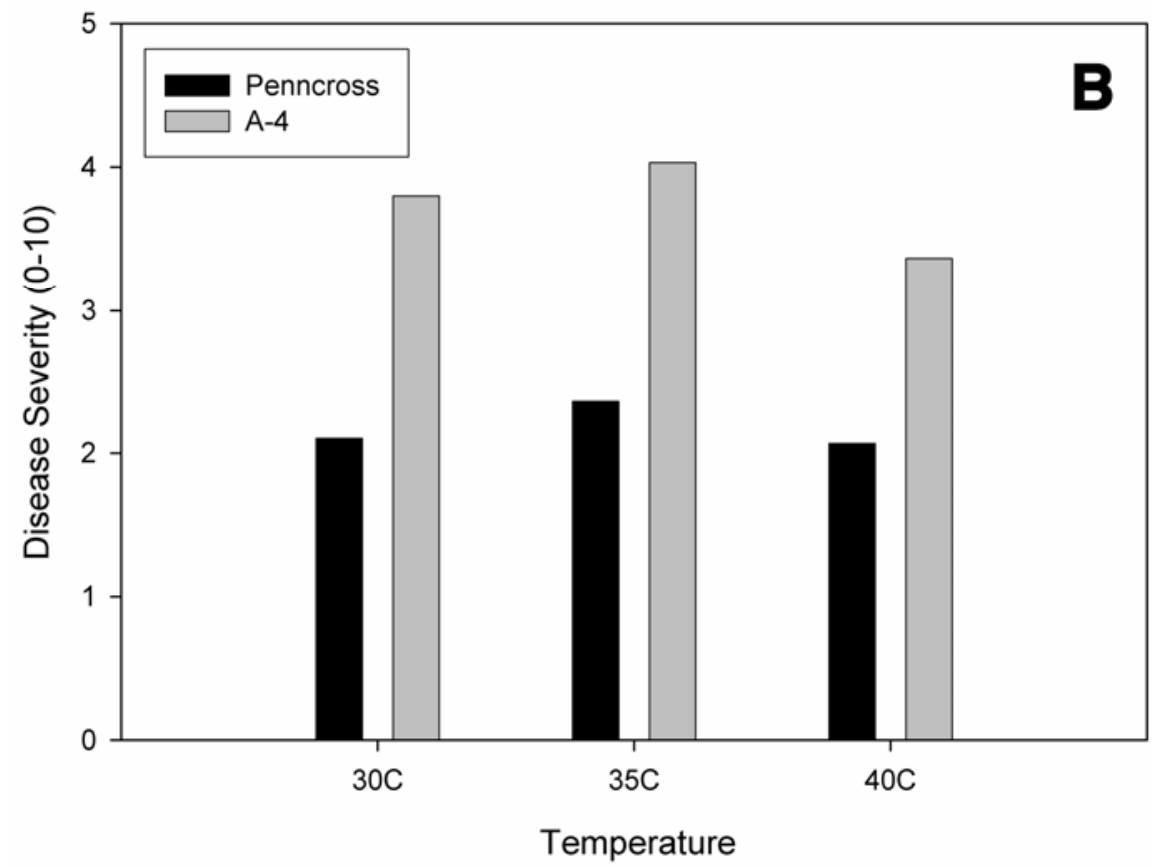

Fig. 2. Summer patch severity in 'Penn A-4' and 'Penncross' creeping bentgrass in response to inoculation with Magnaporthe poae at varying temperatures. A, Experiment 1 and $\mathbf{B}$, experiment 2. Data are averaged across all M. poae isolates and replications for each cultivar and temperature.

Table 2. $P$ values resulting from analysis of variance on disease severity values

\begin{tabular}{|c|c|c|c|c|c|c|c|}
\hline \multirow[b]{2}{*}{ Factor } & \multirow[b]{2}{*}{ DF } & \multicolumn{3}{|c|}{ Experiment 1} & \multicolumn{3}{|c|}{ Experiment 2} \\
\hline & & $30^{\circ} \mathrm{C}$ & $35^{\circ} \mathrm{C}$ & $40^{\circ} \mathrm{C}$ & $30^{\circ} \mathrm{C}$ & $35^{\circ} \mathrm{C}$ & $40^{\circ} \mathrm{C}$ \\
\hline Cultivar & 1 & 0.0453 & 0.0041 & $<0.0001$ & $<0.0001$ & $<0.0001$ & 0.0023 \\
\hline Isolate & 9 & $<0.0001$ & $<0.0001$ & 0.0001 & $<0.0001$ & $<0.0001$ & 0.0001 \\
\hline Replication & 2 & 0.9279 & 0.0070 & 0.1027 & 0.4529 & 0.0077 & 0.317 \\
\hline Cultivar $\times$ isolate & 9 & 0.7331 & 0.5875 & 0.0270 & $<0.0001$ & 0.1560 & 0.1257 \\
\hline
\end{tabular}


from New Jersey, Pennsylvania, and Rhode Island. All of the isolates in clade B were mating type 'A' or sterile and yielded a positive reaction with the $M$. poae $\mathrm{PCR}$ assay.

Clade C contained only isolates from creeping bentgrass in North Carolina. All of the isolates in this clade belonged to mating type 'a,' with the exception of one sterile isolate (TAP62). Interestingly, isolates in clade $\mathrm{C}$ were the only creeping bentgrass isolates to yield a positive reaction with the $M$. poae PCR assay.

Growth chamber inoculations. Significant differences were detected among experiments for disease severity at $30^{\circ} \mathrm{C}(P$ $=0.0173)$ and foliar growth at $35^{\circ} \mathrm{C}(P=$ 0.0039). Also, $P$ values were between 0.05 and 0.1 for disease severity at $35^{\circ} \mathrm{C}(P=$ $0.0514)$ and foliar growth at $40^{\circ} \mathrm{C}(P=$ $0.0865)$. Thus, the results of each experiment are analyzed and presented separately. In experiment 1 , cultivar and isolate had a significant impact on disease severity at all three temperature regimes (Table 2). A significant replication effect was detected only at $35^{\circ} \mathrm{C}$, and a significant cultivar-isolate interaction was detected at $40^{\circ} \mathrm{C}$. The results from experiment 2 were very similar, with the exception of a significant cultivar-isolate interaction at 30 instead of $40^{\circ} \mathrm{C}$. Based on visual assessment of foliar symptoms, disease severity was consistently higher in Penn A-4 than in Penncross in both experiments (Fig. 2).

Eight weeks after inoculation, a small amount of foliar chlorosis and dieback was observed in uninoculated plants due to normal senescence of leaf tissue at high temperatures (Table 3). These background levels generally were higher at $40^{\circ} \mathrm{C}$ than at 30 or $35^{\circ} \mathrm{C}$ in both experiments. Compared with the uninoculated control, most $M$. poae isolates induced significant disease symptoms at 30 and $35^{\circ} \mathrm{C}$. Only isolate OakA5 was nonpathogenic at these temperatures in both experiments. Isolates SpKBG3 and SpKBG7, both from Kentucky bluegrass, were the most virulent toward creeping bentgrass at 30 and $35^{\circ} \mathrm{C}$. A smaller number of isolates caused significant disease at $40^{\circ} \mathrm{C}$, and generally
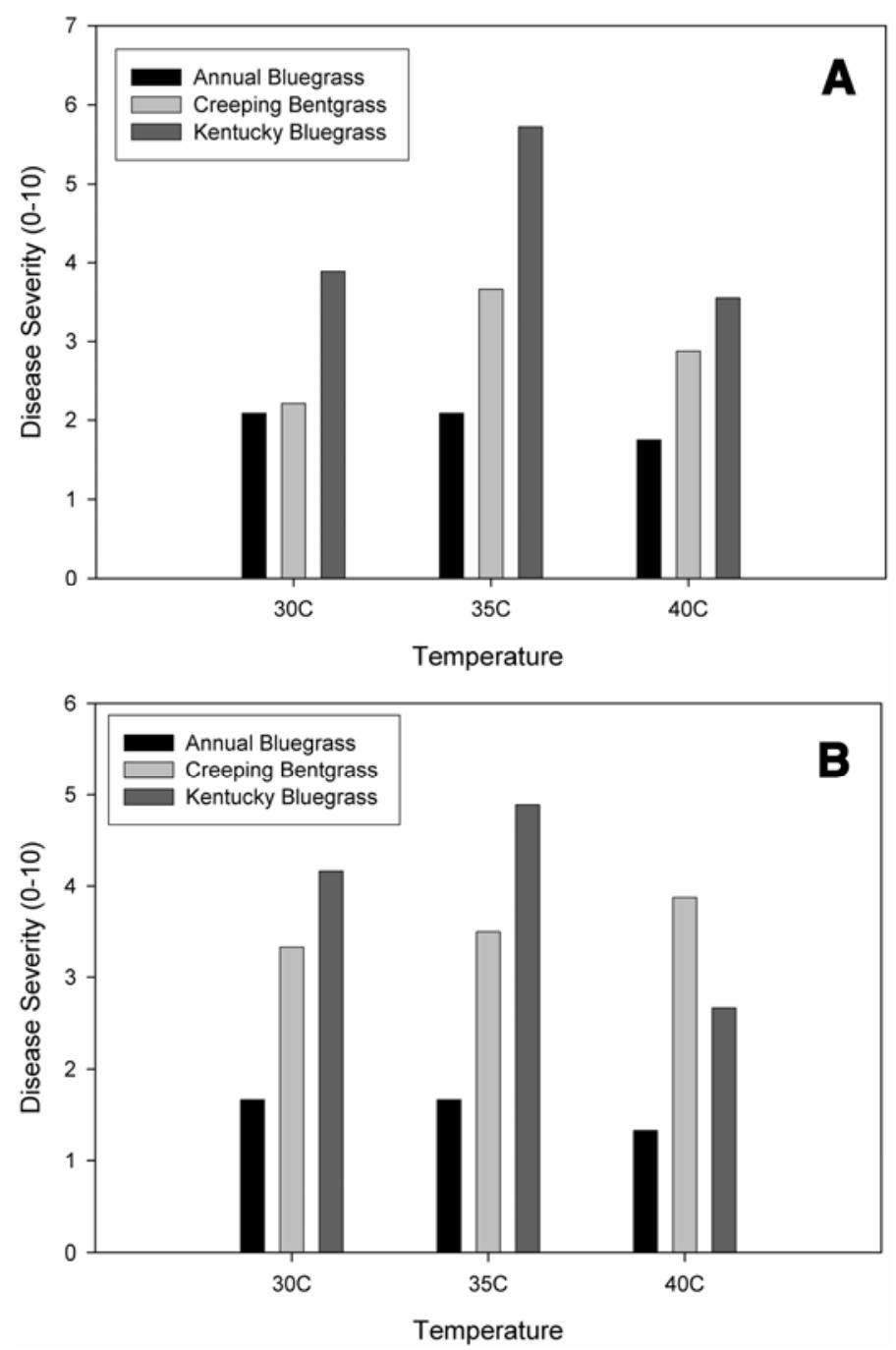

Fig. 3. Summer patch severity in creeping bentgrass following inoculation with Magnaporthe poae from different turfgrass hosts. A, Experiment 1 and B, experiment 2. Data are averaged across cultivars, replications, and host origin of isolates.

Table 4. $P$ values resulting from linear contrasts of foliar growth as influenced by host origin of Magnaporthe poae isolates

\begin{tabular}{|c|c|c|c|c|c|c|}
\hline \multirow[b]{2}{*}{ Contrast $^{\mathrm{z}}$} & \multicolumn{3}{|c|}{ Experiment 1} & \multicolumn{3}{|c|}{ Experiment 2} \\
\hline & $30^{\circ} \mathrm{C}$ & $35^{\circ} \mathrm{C}$ & $40^{\circ} \mathrm{C}$ & $30^{\circ} \mathrm{C}$ & $35^{\circ} \mathrm{C}$ & $40^{\circ} \mathrm{C}$ \\
\hline CrBG vs. KBG & $<0.0001$ & $<0.0001$ & 0.0010 & $<0.0001$ & $<0.0001$ & 0.1168 \\
\hline CrBG vs. $\mathrm{ABG}$ & 0.4165 & $<0.0001$ & 0.0068 & $<0.0001$ & 0.0003 & $<0.0001$ \\
\hline KBG vs. ABG & $<0.0001$ & $<0.0001$ & $<0.0001$ & $<0.0001$ & $<0.0001$ & 0.0163 \\
\hline
\end{tabular}

${ }^{\mathrm{z}} \mathrm{KBG}=$ Kentucky bluegrass, $\mathrm{ABG}=$ annual bluegrass, and $\mathrm{CrBG}=$ creeping bentgrass.

Table 3. Summer patch severity as influenced by Magnaporthe poae isolate and temperature in experiment 1 and experiment $2^{\mathrm{y}}$

\begin{tabular}{|c|c|c|c|c|c|c|c|}
\hline \multirow[b]{2}{*}{ Isolate } & \multirow[b]{2}{*}{ Host origin $^{z}$} & \multicolumn{3}{|c|}{ Experiment 1} & \multicolumn{3}{|c|}{ Experiment 2} \\
\hline & & $30^{\circ} \mathrm{C}$ & $35^{\circ} \mathrm{C}$ & $40^{\circ} \mathrm{C}$ & $30^{\circ} \mathrm{C}$ & $35^{\circ} \mathrm{C}$ & $40^{\circ} \mathrm{C}$ \\
\hline $73-15$ & KBG & $2.00 \mathrm{bcd}$ & $2.17 \mathrm{~d}$ & $1.83 \mathrm{de}$ & $1.83 \mathrm{e}$ & $2.00 \mathrm{ef}$ & $2.00 \mathrm{bc}$ \\
\hline OakA5 & $\mathrm{ABG}$ & $1.67 \mathrm{cde}$ & $0.67 \mathrm{e}$ & $1.67 \mathrm{de}$ & $0.50 \mathrm{f}$ & $0.33 \mathrm{gh}$ & $1.33 \mathrm{c}$ \\
\hline SCR4 & $\mathrm{CrBG}$ & $2.00 \mathrm{bcd}$ & $3.83 \mathrm{c}$ & 2.33 cde & $3.50 \mathrm{~cd}$ & $4.00 \mathrm{~cd}$ & $4.50 \mathrm{a}$ \\
\hline KBG3 & KBG & $4.67 \mathrm{a}$ & $7.67 \mathrm{a}$ & $4.83 \mathrm{a}$ & $4.33 \mathrm{bc}$ & $6.00 \mathrm{ab}$ & $3.67 \mathrm{ab}$ \\
\hline KBG7 & $\mathrm{KBG}$ & $5.00 \mathrm{a}$ & $7.33 \mathrm{a}$ & $4.00 \mathrm{ab}$ & $6.33 \mathrm{a}$ & $6.67 \mathrm{a}$ & $2.33 \mathrm{bc}$ \\
\hline Poa5 & $\mathrm{ABG}$ & $2.50 \mathrm{bc}$ & $3.50 \mathrm{c}$ & $1.83 \mathrm{de}$ & $2.83 \mathrm{de}$ & $3.00 \mathrm{de}$ & $1.33 \mathrm{c}$ \\
\hline TAP35 & $\mathrm{CrBG}$ & $3.00 \mathrm{~b}$ & $4.33 \mathrm{c}$ & $2.83 \mathrm{bcd}$ & $2.67 \mathrm{de}$ & $3.83 \mathrm{~cd}$ & $4.67 \mathrm{a}$ \\
\hline TAP41 & $\mathrm{CrBG}$ & $3.17 \mathrm{~b}$ & $5.67 \mathrm{~b}$ & $3.67 \mathrm{abc}$ & $4.83 \mathrm{~b}$ & $4.67 \mathrm{bc}$ & $2.00 \mathrm{bc}$ \\
\hline TAP42 & $\mathrm{CrBG}$ & $0.67 \mathrm{de}$ & $0.83 \mathrm{e}$ & $2.67 \mathrm{~b}-\mathrm{e}$ & $2.33 \mathrm{e}$ & $1.50 \mathrm{fg}$ & $4.33 \mathrm{a}$ \\
\hline Uninoculated & $\ldots$ & $0.50 \mathrm{e}$ & $0.33 \mathrm{e}$ & $1.33 \mathrm{e}$ & $0.50 \mathrm{f}$ & $0.00 \mathrm{~h}$ & $1.00 \mathrm{c}$ \\
\hline
\end{tabular}

y Values are the means of three replicates. Within a column, means followed by the same letter are not significantly different according to the Waller-Duncan $k$ ratio $t$ test.

${ }^{\mathrm{z}} \mathrm{KBG}=$ Kentucky bluegrass, $\mathrm{ABG}=$ annual bluegrass, and $\mathrm{CrBG}=$ creeping bentgrass. 
only those that were most virulent at lower temperatures, such as SCR4, SpKBG3, SpKBG7, and TAP35. Isolate TAP42 induced significant disease at $40^{\circ} \mathrm{C}$ in experiment 2 , but this isolate was nonpathogenic or weakly virulent in other instances.

Linear contrasts detected significant differences among isolates grouped according to host origin (Table 4). All contrasts were significant with the exception of creeping bentgrass versus annual bluegrass at $30^{\circ} \mathrm{C}$ in experiment 1 and creeping bentgrass versus Kentucky bluegrass at $40^{\circ} \mathrm{C}$ in experiment 2. In general, isolates from Kentucky bluegrass were more virulent than those from annual bluegrass or creeping bentgrass, and creeping bentgrass isolates were more virulent than annual bluegrass isolates (Fig. 3).

From the foliar growth data, analysis of variance detected significant cultivar effects at 35 and $40^{\circ} \mathrm{C}$ in experiment 1 and at 30 and $40^{\circ} \mathrm{C}$ in experiment 2 (Table 5). Foliar growth was lower in Penn A-4 than in Penncross at all temperatures in both experiments (Fig. 4). The cultivar-isolate interaction was significant only at $40^{\circ} \mathrm{C}$ in experiment 1.

Significant isolate effects on foliar growth were detected at all temperatures in experiment 1 and at 30 and $35^{\circ} \mathrm{C}$ in experiment 2 (Table 5). In experiment 1 , all isolates caused a significant reduction in foliar growth at all temperatures compared with the uninoculated control (Table 6). The isolates that induced the highest disease severity values, SpKBG3, SpKBG7, and TAP35, also caused the greatest reductions in foliar growth. In experiment 2, no significant differences were detected in foliar growth at $40^{\circ} \mathrm{C}$. All other isolates caused significant reductions in foliar growth at 30 and $35^{\circ} \mathrm{C}$, with the exception of OakA5, which did not affect foliar growth at $30^{\circ} \mathrm{C}$. Again, the isolates that induced the highest disease severity values, such as SCR4, SpKBG3, SpKBG7, and TAP35, caused the greatest reductions in foliar growth.

Linear contrasts of foliar growth detected significant differences among groups of isolates in most cases (Table 7). In experiment 1 , no differences were detected in creeping bentgrass versus annual bluegrass at all temperatures. In experiment 2, no differences were detected among creeping bentgrass versus Kentucky bluegrass or Kentucky bluegrass versus annual bluegrass at $40^{\circ} \mathrm{C}$. When averaged by host origin of isolates, reductions in foliar growth closely mirrored disease severity values in both experiments, with Kentucky bluegrass isolates causing the greatest reductions, followed by isolates from creeping bentgrass (Fig. 5).

\section{DISCUSSION}

Accurate diagnosis of turfgrass patch diseases is necessary in order to implement effective control practices in a timely manner. Although similar cultural management practices are recommended for take-all patch and summer patch, the timing of
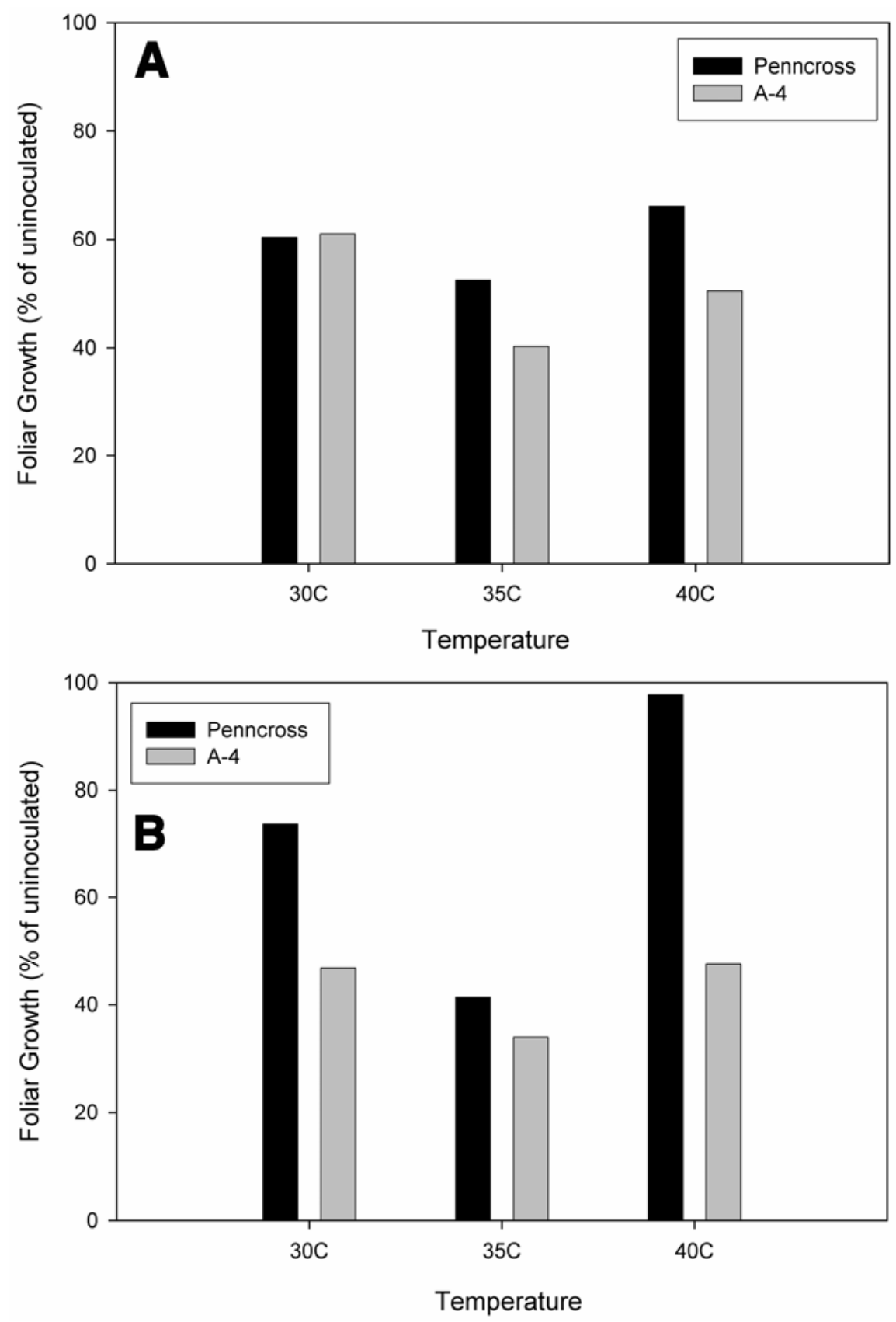

Fig. 4. Foliar growth by 'Penn A-4' and 'Penncross' creeping bentgrass in response to inoculation with Magnaporthe poae at varying temperatures. A, Experiment 1 and $\mathbf{B}$, experiment 2. Data are averaged across all $M$. poae isolates and replications for each cultivar and temperature.

Table 5. $P$ values resulting from analysis of variance on foliar growth values

\begin{tabular}{|c|c|c|c|c|c|c|c|}
\hline \multirow[b]{2}{*}{ Factor } & \multirow[b]{2}{*}{ DF } & \multicolumn{3}{|c|}{ Experiment 1} & \multicolumn{3}{|c|}{ Experiment 2} \\
\hline & & $30^{\circ} \mathrm{C}$ & $35^{\circ} \mathrm{C}$ & $40^{\circ} \mathrm{C}$ & $30^{\circ} \mathrm{C}$ & $35^{\circ} \mathrm{C}$ & $40^{\circ} \mathrm{C}$ \\
\hline Cultivar & 1 & 0.8756 & 0.0017 & 0.0022 & $<0.0001$ & 0.0906 & 0.0047 \\
\hline Isolate & 9 & $<0.0001$ & $<0.0001$ & $<0.0001$ & $<0.0001$ & $<0.0001$ & 0.7576 \\
\hline Replication & 2 & 0.7993 & 0.7256 & 0.0229 & 0.8714 & 0.0001 & 0.1066 \\
\hline Cultivar $\times$ isolate & 9 & 0.6189 & 0.4838 & 0.002 & 0.5909 & 0.2307 & 0.8873 \\
\hline
\end{tabular}


preventative fungicide applications differs between the two diseases (3). The majority of take-all patch development occurs in the fall and spring, when soil temperatures are between 5 and $15^{\circ} \mathrm{C}$. In contrast, $M$. poae is most active during the spring and summer, when soil temperatures are greater than $18^{\circ} \mathrm{C}$. Preventative fungicide applications for take-all patch in the fall and spring are likely to have little impact on the development of summer patch.

The recent characterization of summer patch as a disease of creeping bentgrass reemphasizes the need for accurate diagnosis of turfgrass patch diseases. PCRbased assays have the potential to provide this increase in accuracy. However, the $M$. poae PCR assay developed by Bunting et al. (2) did not positively identify several North Carolina isolates of $M$. poae from annual bluegrass and creeping bentgrass. There is likely additional genetic variation within M. poae that was not accounted for in the isolate collection used to develop this assay. In addition, this assay crossreacted with $M$. rhizophila, a common inhabitant of turfgrass roots, and the rice pathogen $M$. salvinii. Further research is needed to develop a PCR-based assay for identification of $M$. poae that is both robust and specific.

Despite the inability of this PCR assay to identify several North Carolina isolates, ITS sequences detected little diversity within our sample collection. Clade A was the largest clade and contained isolates from all three turfgrass hosts and also both mating types, including the $M$. poae type isolate 73-1. Interestingly, all of the isolates that failed to react with the $M$. poae PCR assay were placed within clade A. The other two clades contained fewer isolates, but these clades were host specific and also contained a single mating type. Clade B contained mating type ' $\mathrm{A}$ ' isolates from annual bluegrass from New Jersey, Pennsylvania, and Rhode Island and clade $\mathrm{C}$ contained mating type ' $\mathrm{a}$ ' isolates from creeping bentgrass. These results indicate that $M$. poae isolates are not limited to a specific turfgrass species, although some
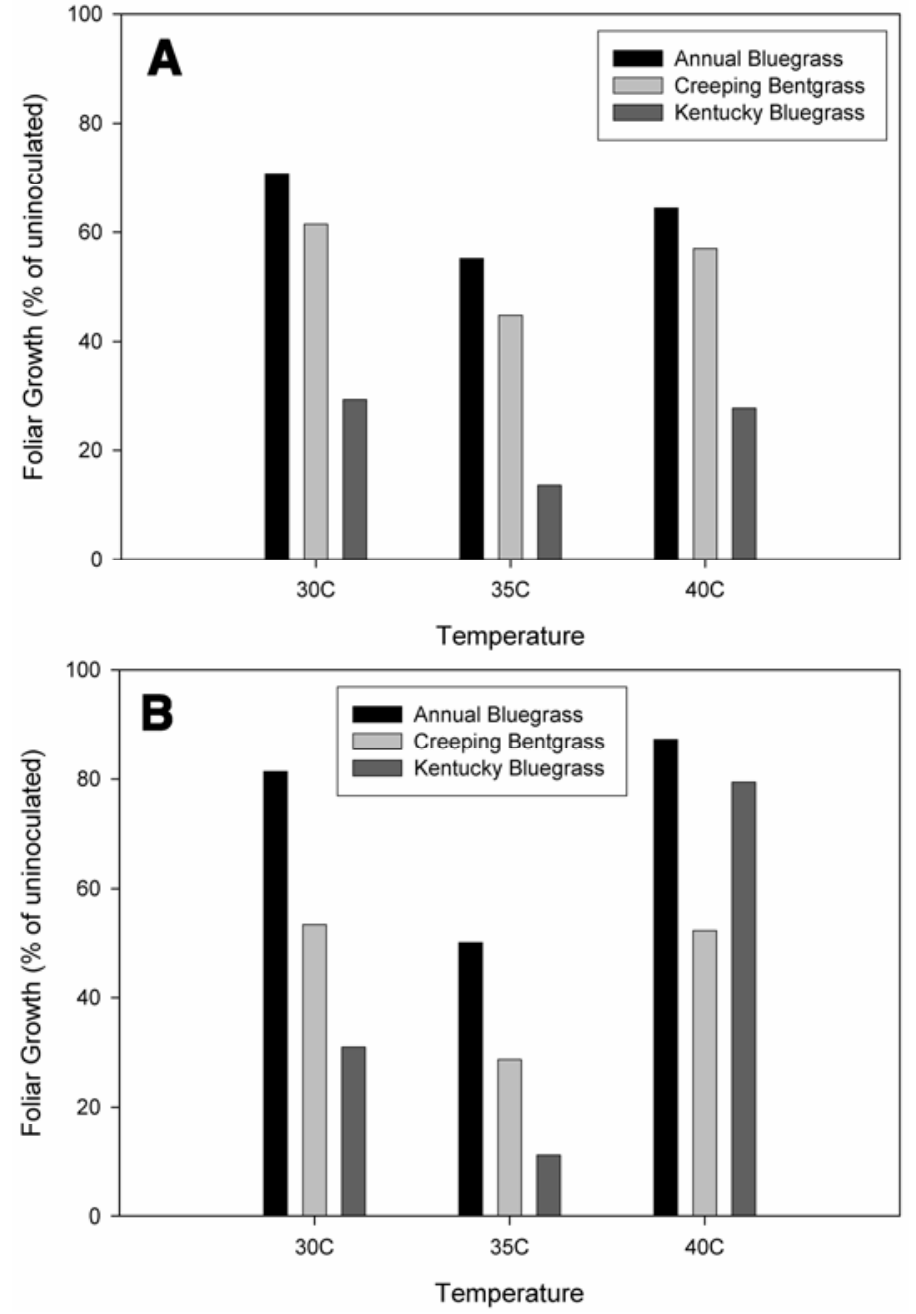

Fig. 5. Foliar growth by creeping bentgrass following inoculation with Magnaporthe poae from different turfgrass hosts. A, Experiment 1 and $\mathbf{B}$, experiment 2. Data are averaged across cultivars, replications, and host origin of isolates.

Table 7. $P$ values resulting from linear contrasts of foliar growth as influenced by host origin of Magnaporthe poae isolates

\begin{tabular}{|c|c|c|c|c|c|c|}
\hline \multirow[b]{2}{*}{ Contrast $^{\mathrm{z}}$} & \multicolumn{3}{|c|}{ Experiment 1} & \multicolumn{3}{|c|}{ Experiment 2} \\
\hline & $30^{\circ} \mathrm{C}$ & $35^{\circ} \mathrm{C}$ & $40^{\circ} \mathrm{C}$ & $30^{\circ} \mathrm{C}$ & $35^{\circ} \mathrm{C}$ & $40^{\circ} \mathrm{C}$ \\
\hline CrBG vs. KBG & $<0.0001$ & $<0.0001$ & $<0.0001$ & 0.0053 & 0.0044 & 0.2443 \\
\hline CrBG vs. $\mathrm{ABG}$ & 0.2412 & 0.0914 & 0.3079 & 0.002 & 0.0011 & 0.1034 \\
\hline KBG vs. ABG & $<0.0001$ & $<0.0001$ & $<0.0001$ & $<0.0001$ & $<0.0001$ & 0.7854 \\
\hline
\end{tabular}

${ }^{\mathrm{z}} \mathrm{KBG}=$ Kentucky bluegrass, $\mathrm{ABG}=$ annual bluegrass, and $\mathrm{CrBG}=$ creeping bentgrass.

Table 6. Foliar growth, expressed as a percentage of uninoculated plants, as influenced by Magnaporthe poae isolate and temperature in experiment 1 and experiment $2^{\mathrm{y}}$

\begin{tabular}{|c|c|c|c|c|c|c|c|}
\hline \multirow[b]{2}{*}{ Isolate } & \multirow[b]{2}{*}{ Host species $^{\mathrm{z}}$} & \multicolumn{3}{|c|}{ Experiment 1} & \multicolumn{3}{|c|}{ Experiment 2} \\
\hline & & $30^{\circ} \mathrm{C}$ & $35^{\circ} \mathrm{C}$ & $40^{\circ} \mathrm{C}$ & $30^{\circ} \mathrm{C}$ & $35^{\circ} \mathrm{C}$ & $40^{\circ} \mathrm{C}$ \\
\hline $73-15$ & KBG & $61.55 \mathrm{~b}$ & $46.52 \mathrm{c}$ & $63.72 \mathrm{~b}$ & $64.26 \mathrm{~b}$ & $39.85 \mathrm{~cd}$ & $83.61 \mathrm{a}$ \\
\hline OakA5 & ABG & $85.25 \mathrm{a}$ & $73.68 \mathrm{~b}$ & $65.15 \mathrm{~b}$ & $112.00 \mathrm{a}$ & $69.52 \mathrm{~b}$ & $92.50 \mathrm{a}$ \\
\hline SCR4 & $\mathrm{CrBG}$ & $61.84 \mathrm{~b}$ & $40.19 \mathrm{~cd}$ & $54.36 \mathrm{~b}$ & $52.84 \mathrm{bc}$ & $22.42 \mathrm{def}$ & $32.36 \mathrm{a}$ \\
\hline KBG3 & KBG & $27.61 \mathrm{~d}$ & $12.64 \mathrm{e}$ & $25.36 \mathrm{c}$ & $35.45 \mathrm{~cd}$ & 14.88 ef & $80.83 \mathrm{a}$ \\
\hline KBG7 & KBG & $30.87 \mathrm{~d}$ & $14.55 \mathrm{e}$ & $30.00 \mathrm{c}$ & $26.47 \mathrm{~d}$ & $7.36 \mathrm{f}$ & $78.06 \mathrm{a}$ \\
\hline Poa5 & $\mathrm{ABG}$ & $56.34 \mathrm{bc}$ & $36.73 \mathrm{~cd}$ & $63.72 \mathrm{~b}$ & $50.76 \mathrm{bc}$ & $30.62 \mathrm{de}$ & $82.08 \mathrm{a}$ \\
\hline TAP35 & $\mathrm{CrBG}$ & $53.35 \mathrm{bc}$ & $41.29 \mathrm{~cd}$ & $71.53 \mathrm{~b}$ & $52.99 \mathrm{bc}$ & $23.48 \mathrm{def}$ & $46.11 \mathrm{a}$ \\
\hline TAP41 & $\mathrm{CrBG}$ & $42.18 \mathrm{~cd}$ & $26.60 \mathrm{de}$ & $36.18 \mathrm{c}$ & $46.00 \mathrm{bcd}$ & 16.66 ef & $57.22 \mathrm{a}$ \\
\hline TAP42 & $\mathrm{CrBG}$ & $88.46 \mathrm{a}$ & $71.18 \mathrm{~b}$ & $66.03 \mathrm{~b}$ & $61.98 \mathrm{~b}$ & $52.13 \mathrm{bc}$ & $73.75 \mathrm{a}$ \\
\hline Uninoculated & $\ldots$ & $100.00 \mathrm{a}$ & $100.00 \mathrm{a}$ & $100.00 \mathrm{a}$ & $100.00 \mathrm{a}$ & $100.00 \mathrm{a}$ & $100.00 \mathrm{a}$ \\
\hline
\end{tabular}

${ }^{y}$ Values are the mean of three replicates. Within a column, means followed by the same letter are not significantly different according to the Waller-Duncan $k$ ratio $t$ test.

${ }^{\mathrm{z}} \mathrm{KBG}=$ Kentucky bluegrass, $\mathrm{ABG}=$ annual bluegrass, and $\mathrm{CrBG}=$ creeping bentgrass. 
host specialization may occur, as indicated by clades $\mathrm{B}$ and $\mathrm{C}$.

The results of growth chamber experiments provide additional support for the conclusion that $M$. poae isolates are not host specific. Indeed, isolates obtained from Kentucky bluegrass were consistently the most virulent toward creeping bentgrass, whereas isolates from annual bluegrass were the least virulent in general. Although the experimental design employed in this study prevents statistical comparisons among temperatures, disease severity and foliar growth reductions in creeping bentgrass were greatest at 35 or $25^{\circ} \mathrm{C}$ for most isolates, regardless of host origin. Previous studies of summer patch development in bluegrass species have found that the optimal temperature for disease development is 29 to $30^{\circ} \mathrm{C}(9,18)$; however, these studies employed constant temperatures as opposed to the diurnal fluctuations used in our experiments. Kackley et al. (9) concluded that temperatures of 25 or $30^{\circ} \mathrm{C}$ favored M. poae growth and also limited host defense responses, but $35^{\circ} \mathrm{C}$ reduced $M$. poae growth and induced a physiological decline of the bluegrass hosts. In our study, summer patch development was greatest at $35 / 25^{\circ} \mathrm{C}$. Diurnal fluctuations that include daytime highs between 30 and $40^{\circ} \mathrm{C}$, which is common in the southeastern United States, may enhance summer patch development in creeping bentgrass. The mechanisms responsible for this increase require further investigation; however, physiological stress alone is not responsible, as evidenced by similar foliar growth in the $35 / 25^{\circ} \mathrm{C}$ and $30 / 25^{\circ} \mathrm{C}$ temperature regimes.

Significant differences in susceptibility to $M$. poae infection were detected among cultivars in this study, with Penn A-4 exhibiting increased disease severity and greater reductions in foliar growth compared with Penncross. This result was unexpected, because Penn A-4 has exhibited increased resistance to take-all patch compared with Penncross in similar growth chamber experiments (23). As more golf course putting greens are established with Penn A-4 instead of Penncross, summer patch may become a more common problem. Although take-all patch and summer patch are similar diseases, the mechanisms of host resistance to these diseases appear to differ. Further research is needed to characterize the mechanisms of resistance to turfgrass patch diseases, to identify additional sources of resistance, and to develop cultivars with improved resistance to these damaging diseases.

\section{ACKNOWLEDGMENTS}

This research was supported by grants from the Center for Turfgrass Environmental Research and Education at North Carolina State University and the North Carolina Turfgrass Foundation. I thank L. Butler and M. Malloy for valuable technical assistance, B. Clarke for providing M. poae isolates from his collection, M. Gumpertz for assistance with statistical analyses, and P. Landschoot and J. Kerns for providing helpful reviews of this manuscript prior to submission.

\section{LITERATURE CITED}

1. Bruneau, A. H., Bigelow, C. A., Cooper, R. J., and Bowman, D. C. 2001. Performance of creeping bentgrass cultivars maintained at two mowing heights and under two fungicide regimes in North Carolina. Int. Turf. Soc. Res. J. 9:835-842.

2. Bunting, T. E., Plumley, K. A., Clarke, B. B., and Hillman, B. I. 1996. Identification of Magnaporthe poae by PCR and examination of its relationship to other fungi by analysis of their rDNA ITS-1 regions. Phytopathology 86:398-404.

3. Dernoeden, P. H. 1993. Integrating strategies for the management of patch diseases caused by root invading ectotrophic fungi. Pages 123161 in: Turfgrass Patch Diseases Caused by Ectotrophic Root-Infecting Fungi. B. B. Clarke and A. B. Gould, eds. American Phytopathological Society Press, St. Paul, MN.

4. Elliott, M. L., des Jardin, E. A., and Henson, J. M. 1993. Use of a polymerase chain reaction assay to aid in identification of Gaeumannomyces graminis var. graminis from different grass hosts. Phytopathology 83:414-418

5. Elliott, M. L. 1993. Association of Magnaporthe poae with a patch disease of creeping bentgrass in Florida. Plant Dis. 77:429.

6. Garrett, S. D. 1956. Biology of Root-Infecting Fungi. Cambridge University Press, Cambridge.

7. Jackson, N. 1993. Geographic distribution, host range, and symptomology of patch diseases caused by soilborne ectotrophic fungi. Pages 17-39 in: Turfgrass Patch Diseases Caused by Ectotrophic Root-Infecting Fungi. B. B. Clarke and A. B. Gould, eds. American Phytopathological Society Press, St. Paul, MN.

8. Juhnke, M. E., Mathre, D. E., and Sands, D. C. 1984. A selective medium for Gaeumannomyces graminis var. tritici. Plant Dis. 68:233-236.

9. Kackley, K. E., Grybauskas, A. P., Hill, R. L., and Dernoeden, P. H. 1990. Influence of temperature-soil water status interactions on the development of summer patch in Poa spp. Phytopathology 80:650-655.

10. Kumar, S., Tamura, K., and Nei, M. 1993. MEGA: Molecular Evolutionary Genetics
Analysis Version 2.1. The Pennsylvania State University, University Park.

11. Landry, G., and Schlossberg, M. 2001. Bentgrass (Agrostis spp.) cultivar performance on a golf course putting green. Int. Turf. Soc. Res. J. 9:886-891.

12. Landschoot, P. J. 1988. Taxonomy and Pathogenicity of Ectotrophic Fungi with Phialophora Anamorphs from Turfgrasses. Ph.D. dissertation, Department of Biological Sciences, University of Rhode Island, Kingston.

13. Landschoot, P. J., and Gullino, M. L. 1993. First report of Magnaporthe rhizophila on Kentucky bluegrass in North America. Plant Dis. 77:1169.

14. Landschoot, P. J., and Jackson, N. 1989. Magnaporthe poae sp. nov., a hyphopodiate fungus with a Phialophora anamorph from grass roots in the United States. Mycol. Res. 93:59-62.

15. Luttrell, E. S. 1958. The perfect stage of Helminthosporium turcicum. Phytopathology 48:281-287.

16. Rachdawong, S., Cramer, C. L., Grabau, E. A. Stromberg, V. K., Lacy, G. H., and Stromberg, E. L. 2002. Gaeumannomyces graminis vars. avenae, graminis, and tritici identified using PCR amplification of avenacinase-like genes. Plant Dis. 86:652-660.

17. Shane, W. W., Stier, J. C., and Nameth, S. T. 1993. Current concepts in disease detection Pages 107-122 in: Turfgrass Patch Diseases Caused by Ectotrophic Root-Infecting Fungi. B. B. Clarke and A. B. Gould, eds. American Phytopathological Society Press, St. Paul, MN.

18. Smiley, R. W., Fowler, M. C., and Kane, R. T. 1985. Temperature and osmotic potential effects on Phialophora graminicola and other fungi associated with patch diseases of Poa pratensis. Phytopathology 75:1160-1167.

19. Tredway, L. P. 2005. First report of summer patch of creeping bentgrass caused by $\mathrm{Mag}$ naporthe poae in North Carolina. Plant Dis. 89:204.

20. Tsuda, M., and Ueyama, A. 1978. Formation of ascigerious stage of Magnaporthe salvinii in culture by the crossing of Japanese isolates. Trans. Mycol. Soc. Jpn. 19:425-431.

21. Vincelli, P., Doney, J. C., Jr., and Powell, A. J. 1997. Variation among creeping bentgrass cultivars in recovery from epidemics of dollar spot. Plant Dis. 81:99-102.

22. Ward, E. 1995. Improved polymerase chain reaction (PCR) detection of Gaeumannomyces graminis including a safeguard against false negatives. Eur. J. Plant Pathol. 101:561-566.

23. Weibel, E. N., Tredway, L. P., and Clarke, B. B. 2002. Impact of temperature and fungal isolate on the susceptibility of bentgrass cultivars to take-all patch. (Abstr.) Phytopathology 92:S146.

24. White, T. J., Bruns, T., Lee, S., and Taylor, J. 1990. Amplification and direct sequencing of fungal ribosomal RNA genes for phylogenetics. Pages 315-324 in: PCR Protocols: A Guide to Methods and Applications, M. A. Innis, D. H. Gelfand, J. J. Sninsky, and T. J. White, eds. Academic Press, San Diego, CA. 